\title{
PENYEBAB KEMISKINAN MASYARAKATTANI \\ (Studi Di Dusun Ngebrong, Desa Tawangsari, Kecamatan Pujon, Kabupaten Malang)
}

\author{
Yohanes Hadi Soesilo \\ Fakultas Ekonomi Universitas Kristen Malang \\ Agus Suman \\ David Kaluge \\ Fakultas Ekonomi Universitas Brawijaya
}

\begin{abstract}
East Java Province was the first province with the largest amount of poor people in Indonesia. Irawan and Romdiati said that in their invention, $72 \%$ of the poor family depend their main income on the agricultural sector and most of them live in village area. This research has been done in Ngebrong Orchard, Tawangsari village Pujon Sub district, Malang Regency and used phenomenology approach in order to find the true reality which is hidden in human awareness that caused the poverty. Some significant findings are found in this research. Firstly, some circumscription, such as geographical Isolation, lack of water resources - depend only on climate and rainy season - has caused them suffer in poverty. Secondly, no monetary and government institution care their need for a non collateral credit and assistance which will help them to leap from their condition. Thirdly, non clear land working agreement makes them have no future stable income assurance. Fourthly, cultural boundaries, such as buwuh culture and poverty hereditary culture make them more powerless. And the last, Fifthly, the acceptance of their present life is a matter of being forced to submission, there is no other way for them to go rather than to accept it, and in fact it will help them happier.
\end{abstract}

Keywords: Poverty, Farm Household, Suistainability

\section{A. LATAR BELAKANG}

Di Jawa Timur, hasil pendataan kemiskinan yang dilakukan oleh Badan Pusat Statistik (BPS) Jawa Timur pada Tahun 2001 menunjukkan bahwa 23.12\% rumahtangga di seluruh Jawa Timur adalah rumahtangga miskin. Bahkan di Tahun 1999, Jawa Timur sempat menduduki peringkat pertama sebagai propinsi dengan jumlah penduduk miskin terbesar di seluruh Indonesia, yaitu sebesar 7.626.074 jiwa (Irawan dan Romdiati 2000). Kabupaten Malang ternyata menduduki peringkat kedua rumahtangga miskin terbanyak untuk seluruh kabupaten di Jawa Timur, yaitu sebesar 134.600 rumahtangga. Dengan jumlah keseluruhan rumahtangga 631.955 , berarti $21.30 \%$ rumahtangga di Kabupaten Malang adalah miskin.

Hal ini sungguh mengherankan, mengingat Kabupaten Malang terkenal sebagai wilayah yang amat subur. Tetapi, hal ini menjadi wajar jika melihat temuan Irawan dan Romdiati (2000) yang mengungkapkan bahwa hampir $72 \%$ dari seluruh rumahtangga miskin dicirikan oleh mereka yang bergantung kepada sektor pertanian sebagai sumber penghasilan utamanya, dan umumnya terdapat di pedesaan. Tujuan penelitian ini adalah mencoba memahami apa yang menjadi penyebab kemiskinan 


\section{Journal of Indonesian Applied Economics Vol.1 No.1 Oktober 2007, 57-67}

masyarakat tani, apa makna temuan ini bagi kita dimasa depan dan prediksi hal-hal yang dapat kita lakukan untuk perbaikan di masa yang akan datang.

\section{B. KERANGKATEORITIS}

\section{Pengertian Kemiskinan}

Baswir (1999) membedakan kemiskinan atas kemiskinan relatif dan kemiskinan absolut. Kemiskinan relatif adalah kemiskinan yang dilihat atas dasar perbandingan tingkat pendapatan antara suatu kelompok masyarakat tertentu dengan kelompok masyarakat lainnya. Sedangkan kemiskinan absolut adalah suatu keadaan kemiskinan yang ditentukan dengan terlebih dahulu menetapkan garis kemiskinan (poverty line), dan yang disebut sebagai masyarakat miskin adalah mereka yang berada di bawah garis kemiskinan.

Eitzen dan Zinn (1993) serta Sarman (1997), mengartikan kemiskinan sebagai kondisi dimana tingkat pendapatan seseorang tidak cukup untuk memenuhi kebutuhan dasar atau kebutuhan pokok, yaitu kebutuhan pangan, sandang, papan, kesehatan dan pendidikan. Amartya Sen dalam Meier (1989) mengatakan, kemiskinan bukanlah sekedar lebih miskin dari yang lain (kemiskinan relatif), tetapi lebih kepada tidak dimilikinya kemampuan untuk memenuhi kebutuhan material secara layak, atau dengan kata lain, kegagalan untuk mencapai tingkat kelayakan minimum tertentu.

Karena kemiskinan dipahami sebagai kegagalan mencapai tingkat kelayakan minimum tertentu, maka secara operasional kriteria tersebut dikaitkan dengan tolok ukur garis kemiskinan. Secara metodologis ada dua pendekatan yang biasa digunakan untuk mengukur kemiskinan, pertama, pendekatan yang mengacu pada metode pendapatan/konsumsi keluarga ( $\mathrm{I} / \mathrm{C}$ method). Kedua, pendekatan yang mengacu pada metode partisipasi, dalam pengertian mengidentifikasi kemiskinan menurut persepsi kelompok miskin itu sendiri (Shaffer 1996 dalam Sarman 1997).

\section{Ukuran Kemiskinan}

Ukuran kemiskinan yang dipakai oleh Bank Dunia, yaitu mereka yang menyandarkan hidupnya pada pendapatan kurang dari 2 dolar AS per hari (Sumodiningrat 2002). Sedangkan ukuran kemiskinan yang digunakan oleh pemerintah Indonesia menurut Umar Juoro dalam Prabandari (1998) dan Jusuf Kalla dalam Tim Liputan 68H(2001), yaitu mereka yang mempunyai penghasilan kurang dari 1 dolar AS per hari untuk warga perkotaan dan 80 sen dolar AS per hari bagi warga pedesaan.

Tahun 2001, BPS Jawa Timur memunculkan indikator kemiskinan baru dalam rangkaian kegiatan yang disebut sebagai Pendataan Kemiskinan dengan Indikator Baru (PKIB). Dibandingkan dengan indikator sebelumnya, indikator PKIB diupayakan lebih operasional. Dengan mengukur 11 variabelvariabel yang dapat dikelompokkan dalam 4 kelompok utama, yaitu: kelompok sandang, kelompok pangan, kelompok papan dan kelompok lainnya (lihat Lampiran 1). Skor dari 11 variabel yang diukur kemudian digunakan untuk menentukan Indeks Rumahtangga Miskin (BPS Jatim 2001).

$$
I_{R M}=\left[\frac{\sum_{i=1}^{11} S_{i} w_{i}}{100}\right]
$$

Dimana

$\mathrm{I}_{\mathrm{RM}} \quad=$ Indeks Rumahtangga Miskin

$\mathrm{S}_{\mathrm{i}} \quad=$ skor variabel $\mathrm{i}$

$\mathrm{w}_{\mathrm{i}} \quad=$ penimbang setiap variable (total penimbang $=100$ )

Nilai $I_{R M}$ memiliki nilai terendah 1 dan tertinggi 3, makin tinggi nilai $I_{R M}$ maka makin miskin suatu rumahtangga. Rumahtangga dengan skor $\mathrm{I}_{\mathrm{RM}} 1$ sampai $(\bar{X}-\sigma)$ termasuk kategori I (tidak miskin atau mendekati miskin), skor $(\bar{X}-\sigma)$ sampai $(\bar{X}+\sigma)$ termasuk kategori II (miskin) dan skor sampai 3 termasuk kategori III (sangat miskin). Hasil PKIB BPS tahun 2001 di Jawa Timur menunjukkan bahwa kategori I mempunyai rentang skor antara 1 sampai 2,44, kategori II antara 2,45 sampai 2,50, kategori III antara 2,51 sampai 3 . 


\section{Penyebab Kemiskinan Masyrakat Tani Soesilo, Suman dan Kaluge}

Walaupun masih memiliki kelemahan, seperti kaburnya jarak antara tiap kategori, namun indikator PKIB ini terasa cukup operasional dan cukup mampu merangkum tidak hanya aspek ekonomi tetapi juga aspek-aspek lainnya, sesuai dengan apa yang dikatakan Amartya Sen dalam Millah (2000), bahwa kekurangan secara ekonomi bukanlah satu-satunya jenis kemiskinan yang merapuhkan kehidupan manusia, karena kehidupan manusia dimiskinkan dalam cara yang berbeda.

Perdebatan mengenai validitas ukuran garis kemiskinan memang selalu muncul menyertai pembahasan kemiskinan itu sendiri. Bagaimana sebenarnya ukuran yang paling pantas untuk mengidentifikasi apakah seseorang atau sekelompok orang itu masuk ke dalam kategori miskin atau sangat miskin. Terlepas masalah validitas indikator yang menentukan garis kemiskinan tersebut, persoalan yang dianggap lebih penting adalah bagaimana cara memberdayakan mereka yang masuk golongan miskin.

\section{Menanggulangi Kemiskinan Dengan Memahami Penyebabnya}

Untuk menanggulangi masalah kemiskinan, maka perlu untuk terlebih dahulu mengetahui faktor-faktor penyebabnya. Menurut Staley dalam Fatchudin (2002), kemiskinan berasal dari fakta bahwa produktivitas total di negara terbelakang sangat rendah sebagai akibat dari: kekurangan modal, pasar yang tidak sempurna, dan keterbelakangan perekonomian. Erwidodo (1999) juga menyatakan, keterbatasan modal dan akses terhadap lembaga keuangan merupakan masalah yang cukup serius yang membuat masyarakat miskin semakin tidak berdaya.

Sumodiningrat (2002) mengatakan, ada dua faktor utama penyebab kemiskinan dan ketidakberdayaan (powerless), yaitu faktor internal dan faktor eksternal. Faktor internal menyangkut permasalahan dan kendala dari dalam individu atau masyarakat miskin yang bersangkutan, seperti: rendahnya motivasi, minimnya modal, lemahnya penguasaan aspek manajemen dan teknologi. Faktor eksternal meliputi: belum kondusifnya aspek kelembagaan yang ada disamping masih minimnya infrastruktur dan daya dukung lainnya sehingga potensi-potensi yang dimiliki masyarakat tidak dapat ditumbuh-kembangkan.

Komplikasi masalah kemiskinan tampak dari kenyataan bahwa di sekitar kita memang terdapat kemiskinan yang disebabkan oleh faktor-faktor kultural dan natural, tetapi di pihak lain, faktor-faktor struktural ternyata juga memainkan peranan yang cukup penting dalam mendorong munculnya masalah kemiskinan (Baswir 1999). Hal tersebut menjadikan fenomena kemiskinan memang harus dilihat dalam perspektif yang lebih komprehensif, bukan parsial. Penanggulangannya juga memerlukan strategi besar yang bersifat holistik dengan program yang saling mendukung satu dengan lainnya. Hasibuan (1997) mengingatkan, kurangnya pemahaman yang dalam mengenai kondisi dan sifat-sifat kelompok masyarakat miskin adalah penyebab utama kegagalan penanggulangan kemiskinan.

\section{Penanggulangan Kemiskinan Melalui Pembangunan Sektor Pertanian}

Menurut Kasyrno (2000), pembangunan pertanian pada dasarnya adalah upaya untuk meningkatkan kualitas hidup petani, yang dicapai melalui strategi investasi dan kebijakan pengembangan profesionalitas dan produktivitas tenaga kerja pertanian, pengembangan sarana dan prasarana ekonomi, peningkatan penguasaan lahan ataupun aset produktif lainnya oleh petani, pengembangan ilmu pengetahuan dan teknologi disertai dengan penataan dan pengembangan kelembagaan pedesaan. Dengan usaha tersebut, diharapkan partisipasi aktif petani dan masyarakat pedesaan dapat ditingkatkan, sehingga peningkatan produksi komoditi pertanian dapat dicapai secara efisien dan dinamis diikuti pembagian surplus ekonomi antar berbagai pelaku ekonomi secara lebih adil. Kebijakan pembangunan pertanian ini juga diharapkan dapat mendorong dan menarik pertumbuhan sektor ekonomi lainnya.

Sasaran pembangunan pertanian adalah meningkatkan kualitas hidup, pendapatan petani dan masyarakat pedesaan melalui peningkatan produktivitas sumberdaya manusia masyarakat pertanian (human capital), peningkatan penguasaan aset produktif pertanian, inovasi teknologi baru, dan menata kebijakan pembangunan ekonomi dan pengembangan kelembagaan pertanian dalam arti luas. Dengan demikian akan terjadi sinergi dan efisiensi keseluruhan mata rantai agrobisnis mulai dari rekayasa teknologi, pembiayaan agrobisnis dan pelayanan, jangkauan pada faktor produksi, produksi pertanian, 


\section{Journal of Indonesian Applied Economics \\ Vol.1 No.1 Oktober 2007, 57-67}

agroindustri pedesaan, dan konsumsi yang bergizi tinggi disertai pengembangan infrastruktur ekonomi pedesaan dan sanitasi (Kasryno 1984, Hazell dan Rosegrant 1999).

Masalah utama yang dihadapi pembangunan pertanian dan pedesaan adalah produktivitas tenaga kerja dan penguasaan aset produktif yang rendah. Kondisi ini yang menyebabkan rendahnya pendapatan masyarakat dan tingginya tingkat kemiskinan pedesaan. Pembangunan pertanian harus dapat meningkatkan produktivitas, pendapatan dan kesejahteraan petani dan masyarakat pedesaan secara dinamis. Dengan demikian pembangunan pertanian harus dapat meningkatkan partisipasi aktif petani dan masyarakat pedesaan melalui pemanfaatan secara optimal sumberdaya manusia petani yang profesional (Kasyrno 2000).

Secara lebih rinci, Kasyrno (2000) mengemukakan strategi yang mungkin diterapkan bagi pembangunan ekonomi pedesaan pada negara yang mengalami surplus tenaga kerja pedesaan. Pertama, peningkatan produktivitas tenaga kerja dan penguasaan aset produktif melalui program broad based productivity growth dengan prioritas pengembangan petani skala kecil dan menengah, serta pengembangan non pertanian pedesaan. Kedua, enam "i" yaitu inovasi, input (sarana produksi), insentif, infrastruktur, institusi (kelembagaan), dan inisiatif. Dengan strategi ini pengembangan pertanian dan non pertanian pedesaan dilaksanakan secara simultan. Ketiga, pengembangan areal pertanian dan land reform untuk mendukung unimodal agrarian structure guna menjamin peningkatan penguasaan aset produktif. Keempat, kebijakan ekonomi makro yang memihak pertanian. Kelima, peningkatan human capital terutama pendidikan, perbaikan kesehatan dan sanitasi. Keenam, peran pelayanan pemerintah terutama dalam penyediaan public goods. Keunggulan broad based agricultural strategy and unimodal agrarian structure atau strategi pembangunan pertanian berspektrum luas dan mengutamakan pertanian rakyat adalah karena potensinya untuk meningkatkan kesempatan berusaha dan kesempatan kerja diiringi peningkatan produktivitas tenaga kerja dan penguasaan aset produktif pertanian yang cepat.

Kelemahan kelembagaan pedesaan menyebabkan sistem ekonomi desa dan pertanian rakyat belum seluruhnya masuk dalam sistem moneter karenanya kegiatan mereka tidak menambah likuiditas ekonomi pedesaan. Hal ini disebabkan investasi petani tidak didukung oleh keberadaan lembaga keuangan ataupun perbankan pedesaan. Semua nilai tambah dari kegiatan investasi yang terjadi jatuhnya justru kepada ekonomi perkotaan karena menggunakan jasa perbankan perkotaan, sedangkan yang diterima oleh masyarakat pedesaan hanya berupa upah minimum regional (Kasyrno 2000).

Pada dasarnya strategi pembangunan mencakup kebijakan investasi, harga dan perdagangan, lembaga keuangan, pengembangan non pertanian, dan desentralisasi manajemen pembangunan. Operasionalisasi paradigma pembangunan ini dilakukan pemerintah melalui, pertama, investasi pemerintah di bidang pendidikan, kesehatan dan sanitasi, pengembangan sarana dan prasarana ekonomi, penelitian dan pengembangan pertanian. Kedua, serangkaian kebijakan pemerintah tadi berpengaruh pula pada pola pengembangan human capital, pola pemanfaatan sumberdaya alam, penataan kelembagaan pertanian dan pedesaan, serta pengembangan teknologi pertanian spesifik lokasi. Ketiga, minat investasi masyarakat di sektor pertanian dan non pertanian dipengaruhi ketersediaan tenaga kerja berkualitas, teknologi, dan kelembagaan pertanian dan pedesaan, serta juga oleh kebijakan pembangunan. Keempat, rangkaian strategi pembangunan ini mempengaruhi pola produksi pertanian dan produksi non pertanian pedesaan. Kelima, kebijakan pemerintah secara langsung berpengaruh pula pada tingkat harga, pola penyerapan tenaga kerja, distribusi aset produktif, yang akhirnya mempengaruhi pola distribusi dan tingkat pendapatan masyarakat.

\section{METODE PENELITIAN DANANALISIS DATA}

\section{Pendekatan Penelitian}

Penelitian ini menggunakan pendekatan perspektif fenomenologi. Fenomenologi pada dasarnya berpandangan bahwa apa yang tampak di permukaan, termasuk pola perilaku manusia sehari-hari hanyalah suatu gejala atau ekspresi dari apa yang tersembunyi di 'kepala dan hati' si pelaku. 


\section{Penentuan Lokasi Penelitian}

Lokasi yang dipilih sebagai laboratorium pada penelitian ini adalah Dusun Ngebrong, Desa Tawangsari, Kecamatan Pujon, Kabupaten Malang. Dasar pertimbangannya, pertama, jumlah rumah tangga miskin di Kabupaten Malang adalah sebesar 134.600, merupakan peringkat kedua terbesar di Jawa Timur (Badan Pusat Statistik Jawa Timur 2001), dan lokasi yang dipilih termasuk di dalamnya. Kedua, sebagai wilayah dengan jenis tanah yang subur, ternyata mayoritas penduduk Dusun Ngebrong masuk dalam kategori miskin. Tentunya kenyataan ini menjadi semakin menarik untuk dikaji. Ketiga, karena letaknya yang terpencil jika dibandingkan dengan wilayah-wilayah lain di Kecamatan Pujon, maka diharapkan Dusun Ngebrong sangat representatif terhadap informasi terkait dengan obyek penelitian. Selain itu, pertimbangan lainnya seperti diungkapkan oleh Moleong dan Yuswadi di atas, juga turut menjadi dasar penentuan laboratorium penelitian ini.

\section{Analisis Data}

Penelitian ini menggunakan analisis data model interaktif terdiri dari tiga komponen utama analisis yang dilaksanakan secara simultan sejak atau bersamaan dengan proses pengumpulan data. Komponen-komponen tersebut adalah reduksi data, penyajian data, dan kesimpulan.

\section{HASIL DAN PEMBAHASAN}

\section{Analisis Tema-tema Kemiskinan Dari Sudut Pandang Fungsi Produksi}

Dari analisis hubungan antara masing-masing tema dengan tema-tema yang lainnya diatas, dapat dikemukakan bahwa fungsi ekonomi masyarakat tani dusun Ngebrong lemah, khususnya pada fungsi produksinya. Hal tersebut terjadi sebagai bagian dari ketidak berdayaan dirinya dalam menghadapi faktor-faktor dasar penentu proses produksi mereka. Lemahnya proses produksi mereka ternyata sangat dipengaruhi oleh keadaan alam dimana mereka tinggal, hal tersebut sangat dominan mempengaruhi kondisi-kondisi yang lain sehingga melemahkan produksi mereka. Kondisi daerah yang terpencil dengan akses jalan yang sulit sehingga biaya transportasi jadi mahal sangat berpengaruh terhadap segala upaya mereka untuk meningkatkan produksi mereka, bahkan hal ini juga menjadi salah satu penyebab sulitnya pelaksanaan program-program asistensi pemerintah, masuknya lembagalembaga pendukung serta kurangnya informasi yang aktual tentang harga pasar, permintaan pasar serta aksesibilitas terhadap kemungkinan-kemungkinan lapangan pekerjaan yang tersedia di sekitar daerahnya. Bahkan meskipun hal itu diterjang, ternyata biaya produksinya (ongkos transportasinya) akan terlalu tinggi bila dibandingkan dengan hasilnya kelak, hal ini secara psikologis memperlemah proses produksi mereka.

Demikian juga karena sumber air yang sulit diharapkan memenuhi kebutuhan mereka untuk berproduksi sepanjang tahun, karena mereka harus sangat tergantung pada iklim dan curah hujan yang membuat mereka tidak dapat berproduksi secara maksimal.

Dalam kaitan yang tidak terlepas dari kondisi alamnya, seringkali juga mempengaruhi wawasan, kemampuan dan stamina kerja para perangkat dusun yang cenderung pasif dan tidak mendapat rangsangan-rangsangan dari luar yang mampu membuat mereka kreatif ataupun berupaya maksimal untuk memperjuangkan nasib rakyat mereka.

Pada sisi yang lain peran dan fungsi Pemerintah jadi terhambat karena faktor alam ini. Kurangnya perhatian dan bimbingan dari Pemerintah untuk meningkatkan fungsi produksi mereka sangat dipengaruhi oleh kurangnya laporan tentang keadaan yang sebenarnya terjadi, tidak sampainya informasi dan bantuan pemerintah ke dusun tersebut bahkan program pemerintah yang tidak sesuai dengan kebutuhan masyarakat, seperti program KUT yang tidak tepat sasaran. Semua itu juga bersumber dan bermuara pada keadaan alam yang terpencil, sulit dijangkau dan lemahnya struktur pemerintahan di tingkat dusun Ngebrong.

Demikian juga dengan ketidak berdayaan mereka karena tidak adanya organisasi dan lembaga-lembaga pendukung yang dapat memimpin dan mengarahkan aktivitas ekonomi mereka 


\section{Journal of Indonesian Applied Economics Vol.1 No.1 Oktober 2007, 57-67}

sehingga fungsi produksi mereka kurang efisien. Keberadaan sturktur organisasi pemerintahan desa yang ada tidak berfungsi dengan baik dalam memperhatikan kebutuhan dan memberikan arahan, kondisi tidak adanya lembaga keuangan yang mau memperhatikan mereka dengan menolong mereka sesuai dengan kondisi dan kebutuhan mereka, mau tidak mau juga dipengaruhi oleh sulitnya daerah tersebut untuk dijangkau, sehingga pemantauan, pembimbingan dan pengarahan yang biasanya diberikan sejalan dengan kredit yang diberikan akan sulit dilaksanakan. Oleh karenanya, daerah ini tidak terjangkau oleh lembaga-lembaga tersebut. Kalaupun ada yang mendapat akses ke arah itu, mereka diperlakukan sama, dengan ketentuan dan syarat-syarat umum yang berlaku, tidak spesifik seperti yang dialami dan dibutuhkan oleh mereka.

Dapat disimpulkan bahwa, semua hal yang tersebut diatas adalah faktor-faktor penyebab lemahnya fungsi produksi masyarakat tani yang ada di dusun Ngebrong dan tampaknya hal-hal tersebut diluar kemampuan mereka untuk dapat mengatasi ataupun mengusahakannya.

Hal-hal lain yang juga sangat mempengaruhi lemahnya fungsi produksi mereka adalah sempitnya wawasan mereka. Sempitnya wawasan tersebut karena kurangnya pendidikan, penyuluhan, bimbingan-bimbingan secara teoritis praktis yang dapat mereka terima. Padahal, sesuai dengan pendapat Sukirno (1987) dalam penelitian Fuad (1995), tingkat pendidikan dan kesempatan belajar tentang segala yang berkaitan dengan kehidupan dan hal-hal yang dihadapi dalam keseharian yang diperoleh seseorang erat kaitannya dengan pola pikir rasionalnya yang akan sangat dibutuhkan baik dalam mengambil keputusan maupun pengembangan sikap terhadap aspek-aspek kehidupan lainnya.

Sempitnya wawasan tersebut ternyata masih juga terkait dengan keterpencilan daerah ini, sarana pendidikan baik di dusun Ngebrong, di dusun Tawangsari dan sekitarnya relatif sangat terbatas, sehingga untuk mengakses sarana pendidikan yang lebih baik dibutuhkan pengorbanan yang besar. Demikian juga bagi para penyuluh dan aparat yang berwajib. Diperlukan suatu pengorbanan dan dedikasi yang tinggi untuk bersedia memperluas wawasan mereka yang sempit itu.

Rendahnya Pendidikan dan kurangnya wawasan ini merupakan salah satu penyebab rendahnya pendapatan mereka, harga jual hasil panen yang tidak sesuai dengan biaya produksi sulit mereka antisipasi. Hasil yang mereka peroleh, tidak dapat mereka kelola dengan baik agar dapat membiayai penanaman berikutnya dan kebutuhan hidup mereka sampai masa panen berikutnya, sehingga dapat disimpulkan bahwa kondisi ini memperparah keadaan mereka yang miskin.

Rendahnya kualitas sumberdaya tersebut menyebabkan petani tidak mampu mengembangkan usahataninya menjadi usahatani yang komersial. Kegiatan usahatani yang dilakukan tidak bisa berorientasi pada permintaan pasar karena kurangnya kemampuan petani untuk mengakses informasi pasar.

Dari hasil wawancara dan pengamatan, terungkap bahwa sebagian besar petani pada umumnya mengusahakan tanaman semusim dengan pola tanam wortel - wortel - jagung dan hasilnya mempunyai nilai jual yang rendah dibandingkan dengan jenis tanaman seperti prei, kentang dan bawang merah yang cenderung mempunyai nilai jual tinggi. Alternatif pemilihan cabang usaha tani yang dikelola petani sangat dipengaruhi oleh kemampuan petani dalam mengalokasikan sumber daya yang dimilikinya baik dari segi pengaturan pola tanam maupun cara bercocok tanamnya. Kemampuan ini sangat dipengaruhi oleh kemampuan akselerasi pola pikir terhadap inovasi teknologi budidaya pertanian yang tentu saja berhubungan erat dengan tingkat pendidikan petani dalam menyerap inovasi teknologi pertanian, baik itu teknologi budidaya maupun teknologi pasca panen. Di samping itu, prediksi harga produk pertanian juga sangat dipengaruhi oleh kemampuan petani dalam menyerap dan menyaring informasi dari pasar domestik maupun regional. Jika petani mempunyai pendidikan yang tinggi, maka kemungkinan besar penyerapan inovasi tersebut dapat membantu petani memperbaiki cara pengelolaan usaha tani menjadi usaha tani komersial yang lebih efisien.

Dapat disimpulkan bahwa wawasan yang sempit sangat mempengaruhi lemahnya fungsi produksi mereka, tetapi ini bukan suatu ketidak berdayaan yang tidak dapat diatasi atau dikendalikan, berbeda dengan faktor alam, struktural dan kelembagaan diatas. Memang untuk dapat mengendalikannya, dibutuhkan suatu tekad, kesadaran, pengorbanan dan upaya terus menerus 


\section{Penyebab Kemiskinan Masyrakat Tani Soesilo, Suman dan Kaluge}

kearah memperluas wawasan diri sendiri dan tentunya juga diperlukan suatu uluran tangan yang kuat yang mau dengan tekun, serius dan penuh komitmen membantu memperluas wawasan mereka.

\section{Analisis Tema-tema Kemiskinan Dari Sudut Pandang Fungsi Konsumsi}

Dari analisis hubungan antara masing-masing tema dengan tema-tema yang lainnya diatas, dapat dikemukakan bahwa fungsi ekonomi masyarakat tani dusun Ngebrong lemah, khususnya bila dilihat dari fungsi konsumsinya, dan hal ini juga memiliki andil dalam memperparah kemiskinan mereka

Tampak bahwa ketidak pedulian perangkat struktural, Pamong Dusun dan Pemerintah sangat mempengaruhi pola konsumsi mereka. Kurangnya wawasan yang memadai, tidak adanya pendidikan masyarakat terhadap pola budaya dan perilaku yang biasa mereka lakukan, seperti "buwuh" dan "konsumerisme" sangat mempengaruhi keputusan dan tindakan mereka dalam menjalani kehidupannya. Budaya mumpung mereka tempuh karena seolah-olah mereka tidak dapat memprediksikan kapan kesempatan yang sama dapat terulang, atau kapankah kesempatan itu dapat diraihnya.

Dalam banyak hal mereka sangat berhemat dalam pola konsumsi mereka untuk hal-hal yang mendasar, seperti makan, minum, pakaian dan tempat tinggal. Mereka cenderung sangat menerima pola konsumsi minimal untuk mempertahankan hidup mereka dalam menyiasati kebutuhan-kebutuhan pokok bagi hidupnya. Tetapi dalam banyak kebutuhan sekunder, mereka jadikan itu seolah-olah kebutuhan primer yang harus diupayakan dan dipaksakan untuk dipenuhi, seperti televisi, sepeda gunung dan berbagai macam trend mainan anak-anak yang sedang digemari.

Memang seringkali hasil yang mereka dapatkan, baik itu dari pekerjaan harian, panen hasil tanaman yang mereka usahakan, hanya cukup untuk membiayai kebutuhan mereka saat itu, hari itu atau paling-paling untuk masa tersebut. Semua habis untuk konsumsi, sehingga setiap kali mereka tidak punya modal untuk memulai suatu pekerjaan, bahkan lebih parah lagi ketika mereka harus mau tak mau, senang tak senang mencari pinjaman hanya untuk sekedar diterima oleh lingkungannya dan tidak dikucilkan karena tidak memberi "buwuh".

Terkesan bahwa masyarakat disana tergolong individu masyarakat yang strukturalis komunalis, dimana mereka tidak berani menyatakan dirinya sendiri sebagaimana yang ia inginkan atau harapkan sebagai seorang pribadi, tetapi ia cenderung lebih menyatakan dirinya sebagai bagian dari komunitas yang ada. Patuh dan menurut pada tatanan yang ada. Sehingga ia tidak akan berani menyatakan dirinya untuk berbeda dengan lingkungannya, atau berekpresi melawan kebiasaan dan perilaku umum serta adat yang biasa dilakukan dan diterima oleh masyarakatnya.

Sehingga dapat disimpulkan, dari sisi fungsi konsumsinya, terjadi hal-hal yang memperparah keadaannya yang miskin, baik itu sebagai hal-hal yang sulit dikendalikannya karena mereka memilih pola hidup yang individual komunalis, seperti "buwuh", tetapi juga karena hal-hal yang seharusnya dapat mereka kendalikan seperti "perilaku konsumerisme"

\section{Analisis Tema-tema Kemiskinan Dari Sudut Pandang Fungsi Distribusi}

Bila diamati pola hubungan yang terjadi diatas, Nampak dengan jelas bahwa pengaruh halhal yang sulit mereka kendalikan sangat dominan dalam menentukan fungsi distribusi mereka. Keterbatasan alam misalnya, khususnya akses jalan yang sulit dan mahalnya transportasi, memperlemah distribusi hasil produksi mereka. Bila mereka harus menunda membawa hasil produksi ke pasar atau mencari teman untuk dapat menyewa kendaraan bersama agar dapat memperingan biaya transportasi, ternyata seringkali terkendala oleh jenis tananman yang mereka hasilkan. Tidak semua tanaman dapat di simpan dulu tanpa mengalami perubahan bentuk dan kualitas. Tetapi bila harus dipaksakan itu berarti tingginya biaya distribusi.

Tidak adanya lembaga Koperasi atau Lembaga Ketahanan Masyarakat Desa, yang tentunya juga tak dapat mereka bentuk sendiri tanpa koordinasi, uluran tangan para otorita, dan kesepakatan bersama, mempersulit mereka untuk mencari jalan alternatif distribusi yang lebih menguntungkan.

Demikian pula Rendahnya Pendidikan dan kurangnya wawasan merupakan salah satu penyebab rendahnya pendapatan mereka, harga jual hasil panen yang tidak sesuai dengan biaya produksi sulit mereka antisipasi. Padahal prediksi harga produk pertanian juga sangat dipengaruhi 


\section{Journal of Indonesian Applied Economics Vol.1 No.1 Oktober 2007, 57-67}

oleh kemampuan petani dalam menyerap dan menyaring informasi dari pasar domestik maupun regional. Demikian juga untuk jalur pendistribusiannya, dibutuhkan suatu informasi permintaan pasar yang dapat diperhitungkan agar dapat diperoleh keuntungan yang lebih baik, sehingga dapat disimpulkan bahwa kondisi seperti ini makin memperparah keadaan mereka yang miskin.

Dalam banyak kasus, karena tidak dimilikinya modal untuk memulai suatu kegiatan ekonomi, sehingga pada saat panen untuk memanen dan menjualnya mereka tidak memiliki modal. Sehingga seringkali mereka menjualnya dengan cara tebasan atau bila panen itu dapat dilakukan dengan tenaganya sendiri, dijualnya hasil panen itu ditepi lahan garapan mereka. Mereka menunggu datangnya para tengkulak atau para makelar (penjual jasa) yang akan membeli hasil panen mereka, walaupun itu berarti harga jual yang rendah, yang ditentukan oleh para tengkulak, harus terpaksa mereka terima.

Kesimpulan yang dapat ditarik dari analisis-analisis yang sudah kita buat diatas, dapat dikatakan bahwa faktor-faktor penyebab kemiskinan masyarakat tani di dusun Ngebrong adalah karena faktor-faktor yang sulit atau tidak dapat dikendalikan oleh mereka secara pribadi, seperti keterbatasan alam karena letak geografisnya serta keterbatasan sumber dayanya, fungsi dan peranan Struktur Pemerintah yang tidak maksimal, Tidak ada dan tidak berperannya serta sulitnya akses pada lembaga-lembaga pendukung sebagaimana yang seharusnya dapat diharapkan. Demikian juga faktorfaktor penyebab kemiskinan masyarakat tani di dusun Ngebrong disebabkan karena faktor-faktor yang secara nyata membelenggu mereka tetapi sebenarnya masih dapat dikendalikan, seperti budaya dan perilaku buwuh, konsumerisme, kurangnya pendidikan dan wawasan, serta jumlah keluarga yang diluar kemampuan untuk membiayai kehidupannya.

\section{E. KESIMPULANDANREKOMENDASI}

Beberapa kesimpulan dan rekomendasi dari temuan kita yang sangat berarti bagi kita saat ini dan juga untuk pemahaman kita ke depan, dapat kita rangkum sebagai berikut:

Keterbatasan-keterbatasan masyarakat tani di Dusun Ngebrong mempunyai andil yang sangat besar dalam menyebabkan kemiskinan mereka. Faktor-faktor itu dapat dikelompokkan dalam dua kategori besar, yaitu: pertama, faktor-faktor yang sulit atau yang tidak dapat mereka kendalikan secara pribadi dan kedua, faktor-faktor yang sulit tetapi sebenarnya masih dapat dikendalikan baik secara pribadi maupun bersama-sama

Faktor-faktor yang sulit atau yang tidak dapat mereka kendalikan secara pribadi adalah:

1. Keterbatasan alam, seperti:

a. Letaknya yang terpencil, jalan jelek dan membutuhkan biaya transportasi yang tinggi. Jauh dari informasi dan akses terhadap lapangan kerja produktif lainnya

b. Keterbatasan sumber air bagi lahan pertanian mereka, mereka sangat tergantung pada musim dan curah hujan

2. Tidak maksimalnya peranan dan fungsi Struktur Pemerintah, seperti:

a. Kurangnya perhatian dari Pamong Dusun terhadap kesejahteraan rakyatnya.

b. Kurang lancarnya informasi dan penjelasan dari Pamong Dusun mengenai penyaluran bantuan dan kredit.

c. Tidak adanya asistensi dan bantuan dari Pemerintah

3. Tidak adanya lembaga-lembaga pendukung, seperti:

a. Lembaga keuangan yang mau memperhatikan kebutuhan mereka yang sesuai dengan keadaan mereka

b. Koperasi dan Lembaga Ketahanan Masyarakat Desa (LKMD

4. Tidak jelasnya sistem pemberian hak pengelolaan lahan garapan oleh Perhutani kerap kali tidak memberikan kepastian jaminan penghasilan yang berkesinambungan, sehingga grafik peningkatan kesejahteraan mereka sebagai hasil upaya dan kerja mereka jadi tidak stabil. 


\section{Penyebab Kemiskinan Masyrakat Tani}

Soesilo, Suman dan Kaluge

Faktor-faktor yang sulit tetapi sebenarnya masih dapat dikendalikan baik secara pribadi maupun bersama-sama adalah:

1. Budaya buwuh, perilaku konsumerisme dan keterbatasan orang tua dalam memfasilitasi sarana bagi percepatan perbaikan hidup yang lebih baik juga menjadi penyebab ketidak berdayaan mereka untuk dapat melompat meninggalkan kubangan kemiskinan mereka.

2. Praktek ijon, dan rendahnya harga jual

3. Rendahnya pendidikan dan sempitnya wawasan

4. Ketidak berdayaan mendapat pekerjaan yang layak, baik karena waktu kerja yang pendek, musim kemarau maupun karena tidak adanya akses terhadap lapangan kerja produktif.

5. Ketidak berdayaan karena tidak adanya modal, akses terhadap lembaga keuangan yang ada dan luas lahan yang sempit.

Sikap mereka yang mau menerima keadaan dengan pasrah sebenarnya hanya suatu keterpaksaan yang harus diambil agar mereka tidak merasakan kemiskinan itu lebih parah dan dalam, karena tertekan secara lahir dan bathin, sebaliknya dengan itu mereka dapat merasakan tingkat kesejahteraan yang lebih baik.

Dari keseimpulan hasil penelusuran di atas, beberapa rekomendasi yang dapat kita upayakan dan lakukan agar dapat menolong masyarakat tani di Dusun Ngebrong ini adalah:

1. Pengupayakan kebijakan-kebijakan yang mengarah kepada peningkatan aksesibilitas terhadap sumber-sumber permodalan:

a. Kredit Usaha Tani tanpa anggunan, tingkat bunga dan jangka pengembalian yang dapat disesuaikan dengan masa panen

b. Kredit usaha tanpa anggunan bagi usaha penyediaan kebutuhan-kebutuhan pertanian (bibit unggul, pupuk, obat-obatan, peralatan pertanian), sehingga menumbuhkan kesempatan bidang pekerjaan pada sektor lain pada kegiatan off-farm.

2. Penyadaran masyarakat petani Dusun Ngebrong melalui tokoh masyarakat setempat mengenai:

a. Sustainability, manajemen hidup yang berorientasi pada kesejahteraan jangka panjang

b. Keberanian menghadapi resiko dari sebuah keputusan atau pekerjaan yang sedang dijalaninya

c. Pentingnya mempunyai pola tanam yang tepat, walau harus berbeda demi hasil yang lebih baik

d. Manfaat keterbukaan dalam memecahkan masalah-masalah hidup (dorongan untuk berani saling sharing, menerima dan memberi pertimbangan serta saran)

3. Mengupayakan adanya sistem pengelolaan lahan garapan yang jelas dan bersistem antara petani dengan pihak perhutani, demi tercapainya kepastian pendapatan yang berkesinambungan.

\section{DAFTAR PUSTAKA}

Abidin, Zainal. (2000) Filsafat Manusia: Memahami Manusia Melalui Filsafat. Remaja Rosda Karya, Bandung.

Alwasilah, A. Chaedar. (2003) Pokoknya Kualitatif. Cetakan Kedua. PT Dunia Pustaka Jaya dan Pusat Studi Sunda, Jakarta.

Badan Pusat Statistik Jawa Timur. (2001) Hasil Pendataan Kemiskinan dengan Indikator Baru Jawa Timur 2001. Badan Pusat Statistik Jawa Timur dan Pemerintah Propinsi Jawa Timur, Surabaya. 
Bafadal, Ibrahim. (2002) Teknik Analisa Data Penelitian Kualitatif. Dalam Metodologi Penelitian Kualitatif, Tinjauan Teoritis dan Praktis (Editor Masykuri Bakri), Cetakan Pertama, hal 173186. Lembaga Penelitian Universitas Islam Malang dan Visipress, Malang.

Bakri, Masykuri. (2002) Pendahuluan. Dalam Metodologi Penelitian Kualitatif, Tinjauan Teoritis dan Praktis (Editor Masykuri Bakri), Cetakan Pertama, hal 1-7. Lembaga Penelitian Universitas Islam Malang dan Visipress, Malang.

Basrowi dan Sukidin. (2002) Metode Penelitian Kualitatif Perspektif Mikro, Cetakan Pertama. Penerbit Insan Cendekia, Surabaya.

Baswir, Revrisond. (1999) Pembangunan pedesaan dan penanggulangan kemiskinan. Dalam Pembangunan Ekonomi Rakyat di Pedesaan Sebagai Strategi Penanggulangan Kemiskinan (Penyunting Hasan Basri), Cetakan Pertama, hal 72-82. Bina Rena Pariwara, Jakarta.

Berger, L. Peter dan Luckmann, Thomas. (1994) Tafsir Sosial Atas Kenyataan. LP3ES, Jakarta.

Bungin, Burhan. (2003) Strategi multi farious-method di dalam penelitian media massa. Dalam Metode Penelitian Kualitatif, Aktualisasi Metodologis ke Arah Ragam Varian Kontemporer (Editor Burhan Bungin), Cetakan Kedua, hal 199-214. PT RajaGrafindo Persada, Jakarta.

Campbell, Tom. (1994) Tujuh Teori Sosial: Sketsa, Penilaian, dan Perbandingan. Kanisius, Yogyakarta.

Craib, Ian. (1986) Teori-teori Sosial Modern: Dari Parson Sampai Habermas. Rajawali Press, Jakarta.

Eitzen, D. Stanley dan Zinn, Maxine Baca. (1993) Social Problems. Fourth Edition. Allyn and Bacon.

Erwidodo. (1999) Modernisasi dan penguatan ekonomi masyarakat pedesaan. Dalam Pembangunan Ekonomi Rakyat di Pedesaan Sebagai Strategi Penanggulangan Kemiskinan (Penyunting Hasan Basri), Cetakan Pertama, hal 3-40. Bina Rena Pariwara, Jakarta.

Faisal, Sanapiah. (2003) Filosofi dan Akar Tradisi Penelitian Kualitatif. Dalam Analisis Data Penelitian Kualitatif, Pemahaman Filosofis dan Metodologis ke Arah Penguasaan Model Aplikasi (Editor Burhan Bungin), Cetakan Pertama, hal 3-12. PT RajaGrafindo Persada, Jakarta.

Fatchudin. (2002) Pengembangan lembaga keuangan mikro dengan model BRI unit untuk pemberdayaan masyarakat nelayan. Makalah falsafah sains Program Pasca Sarjana Institut Pertanian Bogor, Bogor.

Hasibuan, Nurimansjah. (1997) Kemiskinan Struktural di Indonesia: Menembus ke Lapisan Bawah.

Hazell, P. dan Rosegrant M. (1999) Rural Asia: Beyond the green revolution. Makalah yang disampaikan pada The $32^{\text {nd }}$ Annual Meeting Seminar of The Asian Development Bank 29 April 1999, Manila. Asian Development Bank.

Heredia, Carlos A. dan Pueblo, Equipo. (1998) Bank Dunia dan kemiskinan. INFID Publication Page.

Irawan, Puguh B. dan Romdiati, Haning. (2000) Dampak krisis ekonomi terhadap kemiskinan dan beberapa implikasinya untuk strategi pembangunan. Dalam Prosiding Widya Karya Nasional Pangan dan Gizi VII (Editor Ananto Kusuma Seta, Moertini Atmowidjoyo, Sumali M. Atmojo, Abas B. Jahari, Puguh B. Irawan, Tahlim Sudaryanto), Cetakan Pertama, hal 193243. Lembaga Ilmu Pengetahuan Indonesia, Jakarta.

Kanto, Sanggar. (2003) Sampling, Validitas dan Reliabilitas dalam Penelitian Kualitatif. Dalam Analisis Data Penelitian Kualitatif, Pemahaman Filosofis dan Metodologis ke Arah Penguasaan Model Aplikasi (Editor Burhan Bungin), Cetakan Pertama, hal 51-63. PT RajaGrafindo Persada, Jakarta.

Kasryno, Faisal. (2000) Menempatkan pertanian sebagai basis ekonomi Indonesia: Memantapkan ketahanan pangan dan mengurangi kemiskinan. Dalam Prosiding Widya Karya Nasional Pangan dan Gizi VII (Editor Ananto Kusuma Seta, Moertini Atmowidjoyo, Sumali M. Atmojo, Abas B. Jahari, Puguh B. Irawan, Tahlim Sudaryanto), Cetakan Pertama, hal 297-364. Lembaga Ilmu Pengetahuan Indonesia, Jakarta. 


\section{Penyebab Kemiskinan Masyrakat Tani}

Soesilo, Suman dan Kaluge

Meier, Gerald M. (1989) Leading Issues in Economic Development. Oxford University Press, Cambridge.

Miles, B. Mathew dan Huberman, A. Michael. (1992) Analisa Data Kualitatif. UI-Press, Jakarta.

Moleong, Lexy J. (2000) Metodologi Penelitian Kualitatif. Cetakan ketigabelas. PT Remaja Rosdakarya, Bandung.

Prabandari, Purwani Diyah. (1998) Kemiskinan Indonesia dikarenakan misalokasi dana yang luar biasa. Tempo Interaktif edisi Nopember 2001.

Ridjal, Tadjoer. (2003) Metode Bricolage Dalam Penelitian Sosial. Dalam Metode Penelitian Kualitatif, Aktualisasi Metodologis ke Arah Ragam Varian Kontemporer (Editor Burhan Bungin), Cetakan Kedua, hal 82-100. PT RajaGrafindo Persada, Jakarta.

Sarman, Mukhtar. (1997) Kemiskinan dan pemberdayaan ekonomi rakyat: pelajaran dari program IDT. Prisma 1 edisi Januari 1997, hal 33-41.

Sumodiningrat, Gunawan. (2002) Strategi pemberdayaan masyarakat dalam penanggulangan kemiskinan. Materi kuliah umum Program Pasca Sarjana Universitas Brawijaya, Malang.

Sutopo, H.B. (2002) Pengumpulan dan Pengolahan Data Dalam Penelitian Kualitatif. Dalam Metodologi Penelitian Kualitatif, Tinjauan Teoritis dan Praktis (Editor Masykuri Bakri), Cetakan Pertama, hal 115-148. Lembaga Penelitian Universitas Islam Malang dan Visipress, Malang.

Tim Liputan 68H. (2001) Utang dan kemiskinan. Adakah kaitan di antara keduanya? Radio Nederland Wereldomroep Nopember 2001.

Widyaningrum, Nurul. (2002) Model Pembiayaan BMT dan Dampaknya Bagi Pengusaha Kecil, Studi Kasus BMT Dampingan Yayasan Peramu Bogor. Yayasan Akatiga, Bandung.

Wiranto, Tatag. (2003) Profil Kemiskinan di Pedesaan. Urban And Regional Development Institue, Jakarta.

Yuswadi, Hary. (2003) Pengumpulan data di daerah perlawanan petani, sebuah pengalaman lapangan dari Jember. Dalam Metode Penelitian Kualitatif, Aktualisasi Metodologis ke Arah Ragam Varian Kontemporer (Editor Burhan Bungin), Cetakan Kedua, hal 100-107. PT RajaGrafindo Persada, Jakarta. 